\title{
Patterns and Processes of Chasmagnathus granulata and Cyrtograpsus angulatus (Brachyura: Grapsidae) Recruitment in Mar Chiquita Coastal Lagoon, Argentina
}

\author{
T. A. Luppi ${ }^{a \star}$, E. D. Spivak ${ }^{a}$, K. Anger $^{b}$ and J. L. Valero ${ }^{c}$ \\ ${ }^{a}$ Dto. de Biología, FCEyN, UNMDP, c.c. 1245; 7600 Mar del Plata, Argentina \\ ${ }^{b}$ Biologische Anstalt Helgoland, Meeresstation; 27483 Helgoland, Germany \\ ${ }^{c}$ School of Aquatic and Fishery Sciences, University of Washington, Box 355020, Seattle, WA 98195, U.S.A.
}

Received 13 February 2001 and accepted in revised form 21 August 2001

\begin{abstract}
Recruitment patterns of crabs and other benthic invertebrates with planktonic larvae are determined by a combination of pre- and post-settlement factors. Recruitment is considered settlement limited when there is a positive correlation between the postlarvae available in the water column and the number of recruits, and regulated when abundance of individuals is mainly affected by post-settlement factors, such as competence and inter or intraspecific predation. Temperate southwestern Atlantic saltmarshes are inhabited by Cyrtograpsus angulatus and Chasmagnathus granulata, two intertidal grapsid crabs. These crabs are considered key species in the ecosystem in Mar Chiquita coastal lagoon, Buenos Aires, Argentina. In this work, we compare the recruitment pattern of Cyrtograpsus angulatus and Chasmagnathus granulata on the basis of a 3-year sampling programme. Furthermore, we examine experimentally, in laboratory and field, settlement and postsettlement processes that can help explain these patterns: habitat selection, intra- and inter-cohort cannibalism and predator avoidance behaviour. Finally, we integrate our results with the previous knowledge about distribution, growth and reproductive biology of both species, to propose a model of recruitment of each species. Both species had a consistent recruitment pattern through 3 years. Recruitment of both species started at the beginning of summer, and continued to autumn, but recruits were present until the beginning of spring. Densities of recruits and juveniles of $C$. angulatus were not correlated, whereas, there was a relationship between abundance of recruits and juveniles of $C$. granulata. In the field, recruits of $C$. angulatus suffered high mortality caused by intra- and inter-cohort cannibalism. Megalopae of $C$. angulatus selected a substrate (crevices in Ficopomatus enigmaticus reef) that gave them refuge against cannibals. First crabs of $C$. granulata selected adult conspecific substrate (mud from adult habitats). Recruits of $C$. angulatus avoided adults of either species. A qualitative model of recruitment of both species is proposed. Post-settlement processes strongly affects the recruitment pattern and, consequently, both species have regulated recruitment. The degree of such regulation, however, is more intense in C. angulatus than in C. granulata.
\end{abstract}

(C) 2002 Elsevier Science Ltd. All rights reserved.

Keywords: recruitment; cannibalism; refuge; Chasmagnathus granulata; Cyrtograpsus angulatus; coastal lagoon; Argentina

\section{Introduction}

Recruitment in open populations of benthic marine species with complex life cycles is generally defined as the addition of new individuals to a local population, following settlement of the pelagic larval stage (Caley et al., 1996). This process is affected by physical and biological factors during the pelagic as well as subsequent stages (Connell, 1985; Gaines \& Roughgarden, 1985; Mapstone \& Fowler, 1988; Bertness et al., 1992; Eggleston \& Armstrong, 1995; Butler et al., 1997).

^E-mail: taluppi@mdp.edu
Recruitment of species with highly swimming postlarvae includes three components: (1) the amount of postlarvae (e.g. megalopae) in the water column; (2) the active selection of a suitable settlement habitat by the postlarvae; and (3) the survival of settled megalopae and early postsettlement stages (Eggleston \& Armstrong, 1995; Moksnes et al., 1997). Recruitment is considered settlement limited when there is a good correlation between larval settlement (directly related to the amount of postlarvae available in the water column) and abundance of subsequent stages (juveniles or adult) (Connell, 1985; Doherty \& Williams, 1988). Conversely, recruitment is considered regulated if population density is mainly 
affected by post-settlement factors, such as competence or inter- and intra-specific predation (Hughes, 1990; Butler et al., 1997). Hence, recruitment patterns are determined by a combination of pre- and post-settlement factors. Previous studies have found that mobile crustaceans may have limited (Pearce \& Phillips, 1988; Caputi et al., 1995; Palma et al., 1998) and regulated (Steger, 1987; Incze \& Wahle, 1991; Eggleston \& Armstrong, 1995; Moksnes et al., 1997; Palma et al., 1998; Moksnes, 1999) recruitment.

The presence of settlers and recruits in a particular habitat, and not in all the available ones, can be explained by either or both of two processes: habitat selection and differential mortality among habitats. Historically, the hypothesis of differential mortality due to predation has been first proposed as the cause of the correlation between macrofauna abundance and habitat complexity (Heck \& Orth, 1980; Stoner, 1980). Density-dependent mortality has been reported as the most important post-settlement factor affecting recruitment in decapods (Olmi et al., 1990; Wahle \& Steneck, 1991; Eggleston \& Armstrong, 1995; Palmer et al., 1996; Moksnes et al., 1997; Moksnes, 1999). In recent years, however, evidence has accumulated supporting habitat selection as an important process influencing the distribution of recruits (Bell \& Westoby, 1986; Fernandez et al., 1993a; Eggleston \& Lipcius, 1992; Eggleston \& Armstrong, 1995). Several decapods actively select complex habitats (Botero \& Atema, 1982; Herrnkind \& Butler, 1986; Bell \& Westoby, 1986; Fernandez et al., 1993a). Some crab megalopae have the ability of swimming and manoeuvring under conditions similar to those found in their settlement habitats (Luckenbach \& Orth, 1992; Fernandez et al., 1994) and of selecting substrates under running water conditions (Hedvall et al., 1998).

Temperate southwestern Atlantic saltmarshes are inhabited by dense populations of two grapsid crabs, Cyrtograpsus angulatus (Dana 1851) and Chasmagnathus granulata (Dana 1851) (Olivier et al., 1972a; Spivak et al., 1994). Both species show seasonal reproductive activity pattern, with a maximum percentage of ovigerous females found in the beginning of summer, and produce several egg clutches until late summer. The reproductive season is longer in C. angulatus (September to May) than in $C$. granulata (October to March) (Spivak et al., 1996). Both export larvae (as zoea I) to the ocean (Anger et al., 1994), and returning megalopae are capable of swimming actively under the current velocities usually found in the field and of selecting a substrate (Valero et al., 1999). Recruits (early postsettlement stages; crab instars 1 to 3 ) and juveniles of these species utilize different habitats: those of $C$. granulata were found in burrows of adult individuals; whereas polychaete ' reefs', stones and empty pelecypod valves are the specific substrate of those of $C$. angulatus, (Spivak et al., 1994; Luppi et al., 1994; Gutierrez \& Iribarne, 1999). High densities of burrows of $C$. granulata are found in tidal flats and Spartina densiflora grassland of the central and outer parts of the lagoon. Adults of $C$. angulatus are predominantly found at the lower intertidal level and in the adjacent subtidal, but frequently also on rocky sea shore (Spivak et al., 1994). Trophic studies of these species have shown the presence of conspecific remains in their diets (Olivier et al., 1972b; D'Incao et al., 1990). In the laboratory, there was a high mortality of recruits due to cannibalism by juveniles, even in the presence of artificial refuges (Luppi, 1999).

In this work, we examine and compare the recruitment pattern of Cyrtograpsus angulatus and Chasmagnathus granulata on the basis of a 3-year sampling programme. Furthermore, we examine experimentally, in the laboratory and in the field, settlement and post-settlement processes that help to explain these patterns: habitat selection, cannibalism and predator avoidance behaviour. Finally, we integrate our results with previous knowledge about distribution, growth and reproductive biology of both species, to propose a model of recruitment of each species.

\section{Materials and methods}

\section{Study area}

Mar Chiquita coastal lagoon is located between $37^{\circ} 32^{\prime}$ to $37^{\circ} 45^{\prime} \mathrm{S}$ and $57^{\circ} 19^{\prime}$ to $57^{\circ} 26^{\prime} \mathrm{W}, 35 \mathrm{~km} \mathrm{NE}$ of the city of Mar del Plata, Argentina (Figure 1). It has an area of $46 \mathrm{~km}^{2}$, a maximum depth of $c a \cdot 1 \cdot 2 \mathrm{~m}$ (Fasano et al., 1982) and it is divided into a wide northern and a narrow southern part. The present study was conducted in the southern part, near the mouth of the lagoon, where salinity shows high and sometimes rapid variations, ranging from oligohaline to fully marine conditions (Anger et al., 1994). Small creeks feed it constantly with freshwater. Semidiurnal (low amplitude $<1 \mathrm{~m}$ ) tides superimposed by irregular, often strong, wind action cause an irregular pattern of influx and out flux of water, which is hampered by a sandbar in the entrance of the lagoon (Anger et al., 1994; Reta et al., 1997). Intertidal environments at the lagoon comprise mud flats and large areas of cordgrass, Spartina densiflora, along the perimeter (Olivier et al., 1972a, Iribarne et al., 1997). The homogeneous muddy substratum is altered by reefs of 


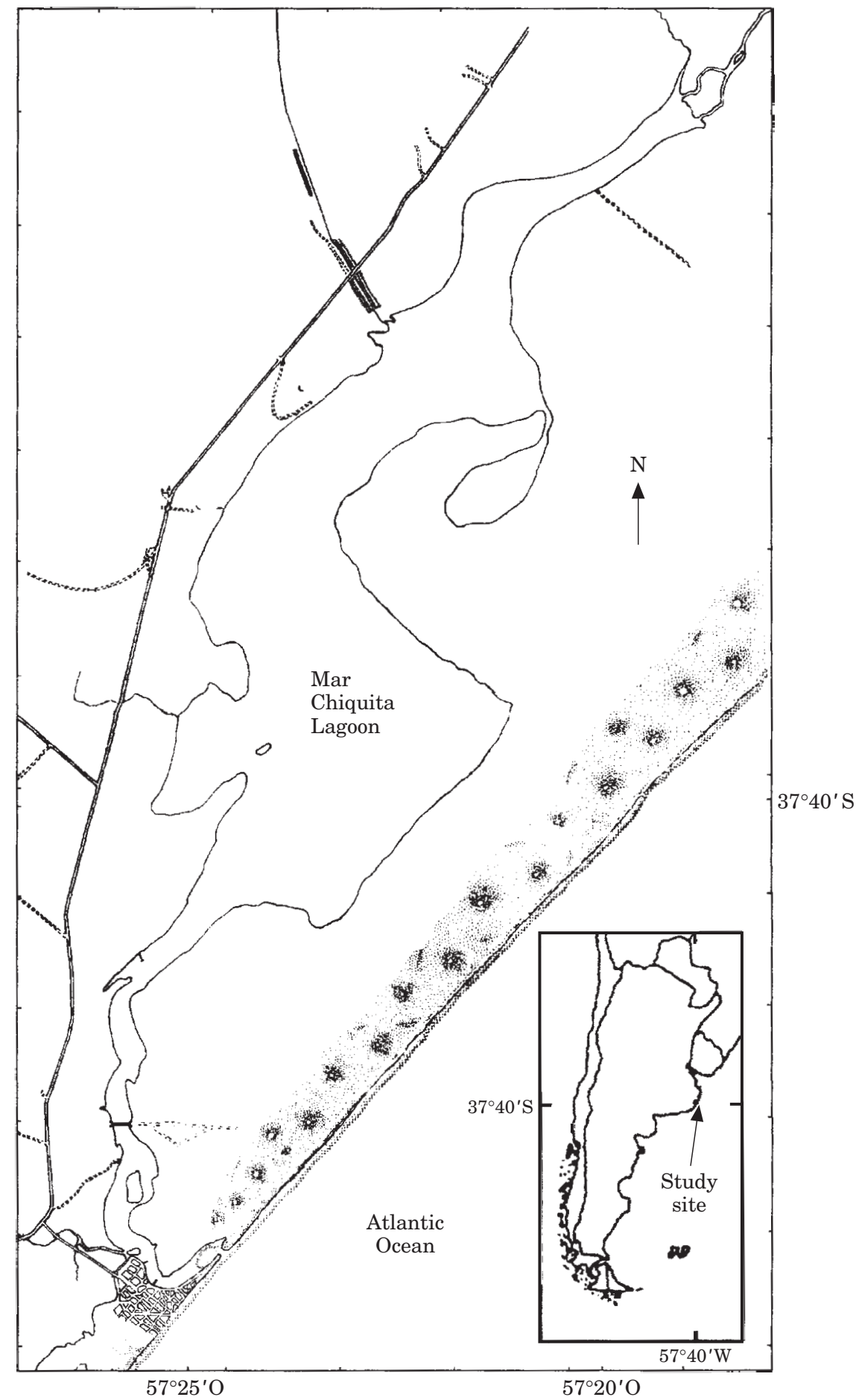

FIGURE 1. Map and geographical position of Mar Chiquita coastal lagoon.

Ficopomatus enigmaticus, a tube-building polychaete that have invaded most of the lagoon $(\cong 80 \%)$ (Shwindt \& Iribarne, 2000), and, occasionally, by consolidated Pleistocene continental sediments (Fasano et al., 1982).

\section{Recruitment habitat and patterns}

To investigate the recruitment pattern of both crab species, we carried out a field sampling programme through 3 years. On a thrice-a-month (summer) or 
bimonthly (winter) basis, from October 1992 to December 1995, we sampled recruits and juveniles of Cyrtograpsus angulatus from reefs of Ficopomatus enigmaticus, and those of Chasmagnathus granulata from a muddy tidal flat characterized by a great density of adult burrows. The total number of collections were 54 (C. angulatus) and 49 (C. granulata), always in the same site. Crabs of $C$. angulatus hidden in reefs were obtained from 10 samples per collection date with a cylindrical corer (diameter: $7 \mathrm{~cm}$, volume: $300 \mathrm{~cm}^{3}$ ), whereas those of $C$. granulata were obtained by digging them out from randomly chosen $0.25 \mathrm{~m}^{2}$ sampling areas in a transect parallel to the shore (samples per collection date $=3$ to 11 ). All the individuals of each sampling unit were collected and their carapace width (CW) measured with a binocular microscope to the closest $0.01 \mathrm{~mm}$. Crabs $<3.2 \mathrm{~mm}$ (C. angulatus) and $<2.9 \mathrm{~mm}$ (C. granulata) were called 'recruits', those larger, 'juveniles'. The size limit between recruits and juveniles was calculated, for each specie, as the middle point between the average $\mathrm{CW}$ of laboratory reared third and fourth crab instars (Luppi, 1999). Recruit and juvenile average densities were calculated for each species and sampling date.

\section{Cannibalism of Cyrtograpsus angulatus recruits}

To evaluate the effect of recruit density on predation rates by intra- and inter-cohort cannibalism we designed a field experiment. C. angulatus megalopae collected in the field in February 1998 were taken to the laboratory and held until they moulted to the first crab instar (C1). Groups of 12, 24 and 48 C1 (preys), a piece of reef ( $c a .500 \mathrm{ml})$ as refuges and four juveniles (CW 7-8 mm) (predators) were placed in 31 plastic containers $(13.5 \times 13.5 \times 16 \mathrm{~cm})$ with $500 \mu \mathrm{m}$ mesh walls. Refuges also contained other possible preys (e.g. amphipods, polychaets) and detritus. Four replicates were used for each recruit density in the absence of predators (intra-cohort cannibalism) and seven replicates with predators were used for each recruit density (inter-cohort cannibalism). Each container was placed in the lagoon, hanging from a pole at $30 \mathrm{~cm}$ from the bottom. After 8 days, the surviving recruits were counted and proportional mortality was expressed as the proportion of recruits that died during the experiment. A two-way ANOVA was used to test the null hypothesis of no differences in mortality rate among different densities of prey and presence-absence of predators. To meet assumptions of normality and homogeneity of variance, proportional mortality of recruits were $\log (x+1)$ transformed.

\section{Substrate selection}

In order to determine if megalopae and C1 display a preference between polychaete tube reef and mud substrate two substrates were offered: (1) a piece of 'clean' reef (without macrofauna, ca. $100 \mathrm{ml}$ ) and (2) the same volume of mud, collected in the settlement habitat of Chasmagnathus granulata, distributed in a $33 \mathrm{~cm}^{2}$ surface. Both substrata were placed at the bottom of a plastic container (diameter $28 \mathrm{~cm}$, height $16 \mathrm{~cm}$, filled with 1.51 water of salinity $=23 \mathrm{PSU}$ ), separated $5 \mathrm{~cm}$ and at $5 \mathrm{~cm}$ from the wall. In order to minimize the effect of light over movements of megalopae, the line joining both substrata were oriented following a random generated set of angles. Each container was closed at the start of the experiment. Megalopae were collected in the field using bag collectors deployed in the lagoon's water column; only megalopae without autotomies and in intermoult stage (Luppi \& Spivak, 1999) were used, the remaining were kept in the laboratory until moulting to $\mathrm{C} 1$. Each trial consisted of 10 replicates with 10 individuals (megalopa or C1) in each container; individuals were used only once. Megalopae or C1 were placed in the centre of the container with a pipette and the total number of individuals in each substrate was registered after $2 \mathrm{~h}$. Those that did not select a substratum (i.e. found swimming or resting in the bottom of the container) were not considered in further analyses. After tested the homogeneity of replicates, data were pooled and analysed using a $\chi^{2}$ test.

\section{Adult avoidance behaviour}

In order to observe if recruits of Chasmagnathus granulata and Cyrtograpsus angulatus have different behaviours in the presence of conspecific or interspecific adults, we performed a laboratory experiment. Recruits were collected in their specific settlement habitats between February and March 1996. They measured (mean \pm standard deviation) $1.8 \pm 0.25 \mathrm{~mm}$ and $1.95 \pm 0.3 \mathrm{~mm} \mathrm{CW}$, respectively. Experiments were conducted in plastic containers (34 cm long, $27 \mathrm{~cm}$ width and $17 \cdot 5 \mathrm{~cm}$ height, filled with 1.51 water of salinity $=23$ PSU) divided by a wire screen which allowed the free circulation of recruits but not of adults. Eight replicates were used for each combination of recruits and adults (males or ovigerous females) of the same or the other species plus eight control replicates without adults. Five recruits were placed in each side of the container and one male or ovigerous female ( $>25 \mathrm{~mm} \mathrm{CW}$ ) was randomly placed in one side. The containers were placed in a dark room and covered to minimize phototactic effects. 

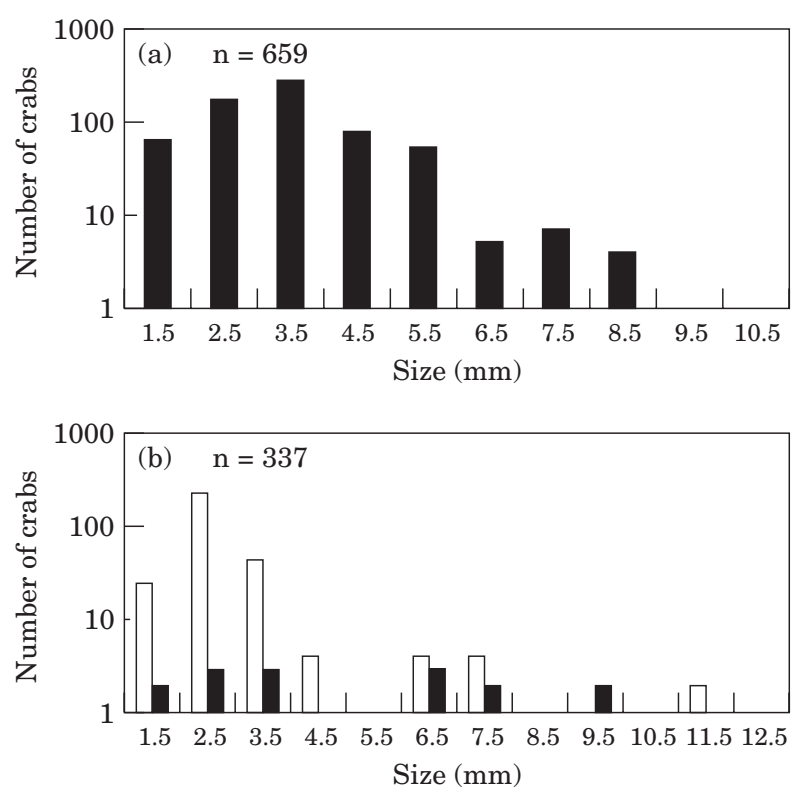

FIGURE 2. Size frequency distributions of recruits and juveniles of (a) Cyrtograpsus angulatus and (b) Chasmagnathus granulata in their recruitment habitats (mud flat and zone with Ficopomatus enigmaticus reefs, respectively), on 21 January 1993. $\square$ In adult burrow; $\square$ out adult burrow.

The position of recruits on either side of the container was recorded after $15 \mathrm{~min}$. Recruits adhered to wire screen were excluded. The results were analysed with a $\chi^{2}$ goodness of fit test.

\section{Results}

Recruitment habitat. The size frequency distributions of crabs collected in two recruitment habitats on 21 January 1993 were skewed (Figure 2). From a total of 337 Chasmagnathus granulata collected, 310 were recruits and small juveniles $(<4 \mathrm{~mm} \mathrm{CW})$. Of these, $97 \%$ were found inside adult burrows. The larger juveniles $(4-12 \mathrm{~mm}$ of carapace width, $\mathrm{n}=27)$ appeared both inside $(59 \%)$ and outside $(41 \%)$ adult burrows. Ficopomatus enigmaticus reefs were the habitat for Cyrtograpsus angulatus recruits and juveniles until $9 \mathrm{~mm}$ of carapace width $(\mathrm{n}=659)$; the modal class corresponds to recruits and small juveniles $(3 \cdot 0-3.9 \mathrm{~mm} \mathrm{CW})$. The coexistence of megalopae, juveniles or adults of both species in the same sample was extremely low.

Recruitment patterns. Recruits of both species were present during summer, autumn, winter and the beginning of spring. Recruitment to the specific settlement habitat (i.e. the first record of C1) began 23, 14 and 21 days earlier for Cyrtograpsus angulatus (29
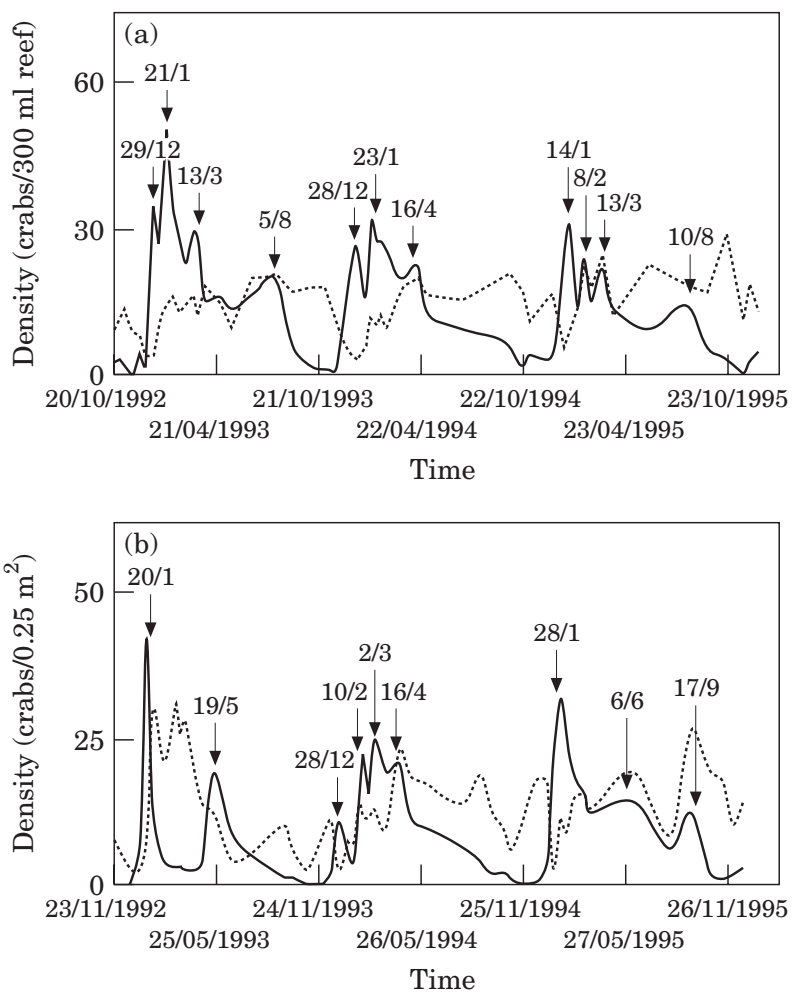

FIGURE 3. Recruitment pattern. Average density of recruits and juveniles of (a) Cyrtograpsus angulatus (crabs/300 $\mathrm{ml}$ reef) and (b) Chasmagnathus granulata (crabs $/ 0 \cdot 25 \mathrm{~m}^{2} \mathrm{mud}$ flat) in their recruitment habitats, in Mar Chiquita lagoon, October 1992 to December 1995. (a) - - Juveniles ( $>3.2 \mathrm{~mm})$, Recruits (<3.2 mm); (b) - - Juveniles $(>2.9 \mathrm{~mm}), \longrightarrow$ Recruits $(<2.9 \mathrm{~mm})$.

December 1992; 14 December 1993; 14 December 1994) than for Chasmagnathus granulata (20 January 1993; 28 December 1993; 4 January 1995). The number of $C$. angulatus recruits increased at the beginning of summer (December), its value was always $>15 \mathrm{crabs} / 300 \mathrm{ml}$ in January, February and part of March, and decreased in late March or April (Figure 3). During this season of high recruit density, three peaks of high recruitment (with densities from 21 to $50 \mathrm{crabs} / 300 \mathrm{ml}$ ) were observed each year. Each peak included three or more collection dates. The peaks of high recruitment were more evident when only first crabs were considered (data not shown). The first and the second peaks were separated 23 to 26 days. The third peak, always smaller, took place more than 33 days after the second one. Few recruits were present in winter and the following spring. However, an additional winter (August) peak was evident in 1993 and 1995. The number of juveniles was rather constant except for a drop just before recruit increase (Figure 3).

The pattern of $C$. granulata recruit density differed through the sampling period. In 1993 there were two 


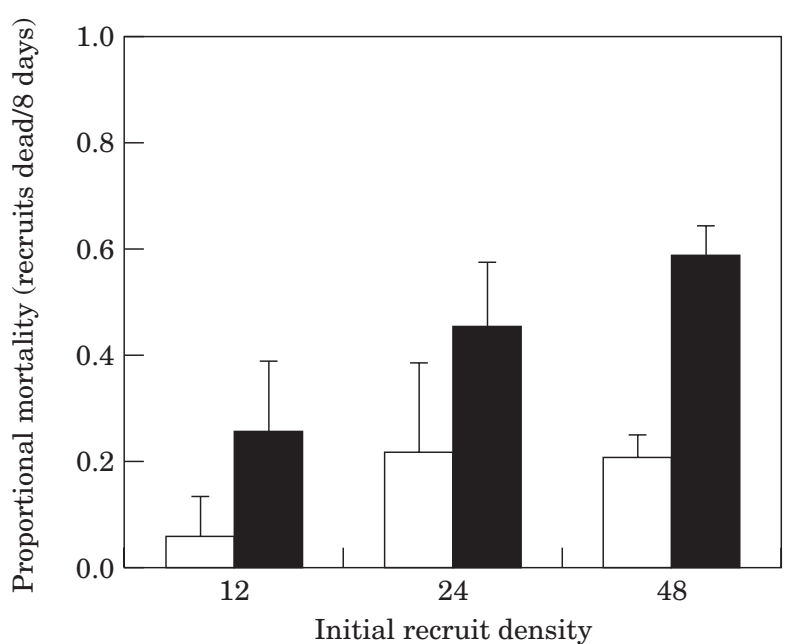

Figure 4. Cannibalism of juvenile Cyrtograpsus angulatus over recruits in field experiments. Proportional mortality (mean \pm standard deviation) of recruits after 8 days, with three initial densities of recruits $(12,24$ and 48 first instar crabs) and presence or absence of predators (4 conspecific juveniles). All replicates with refuge $(500 \mathrm{ml}$ of reef of Ficopomatus enigmaticus). Number of replicates in brackets. $\square$ Without predators $(\mathrm{n}=4)$; $\boldsymbol{\square}$ with predators $(\mathrm{n}=7)$.

peaks of high recruitment (42 crabs $/ 0.25 \mathrm{~m}^{2}$ in January and 19 crabs $/ 0.25 \mathrm{~m}^{2}$ in May) separated by a period of very low density $\left(<3 \mathrm{crabs} / 0 \cdot 25 \mathrm{~m}^{2}\right)$. In 1994 there was a small peak at the beginning of summer $\left(10 \mathrm{crabs} / 0 \cdot 25 \mathrm{~m}^{2}\right)$ followed by a decrease ( $3 \mathrm{crabs} / 0 \cdot 25 \mathrm{~m}^{2}$ ) and three higher peaks in February, March and April (22-24 crabs $\left./ 0 \cdot 25 \mathrm{~m}^{2}\right)$. In 1995 there were three peaks: $32 \mathrm{crabs} / 0 \cdot 25 \mathrm{~m}^{2}$ in January, $14 \mathrm{crabs} / 0 \cdot 25 \mathrm{~m}^{2}$ in June and $12 \mathrm{crabs} / 0.25 \mathrm{~m}^{2}$ in August. The number of juveniles oscillated through the year and had peaks after $(1993,1994)$ or simultaneous with recruit peaks (1995) (Figure 3). The peaks pattern was more evident when only first crabs were considered (data not shown).

Cannibalism of juveniles of Cyrtograpsus angulatus over recruits. Proportional mortality of recruits was significantly affected by their density, both in absence and presence of predators (Figure 4). Comparing the extreme densities of 12 to 48 recruits, proportional mortality increased from $0.06 \pm 0.08$ to $0.21 \pm 0.04$ in absence of predators and from $0.21 \pm 0.13$ to $0.59 \pm 0.06$ in their presence. (ANOVA, $F_{\text {prey density }}=17 \cdot 8, P<0 \cdot 001 ; F_{\text {predator }}=59$, $\left.P<0.001 ; F_{\text {interaction }}=1.19 ; P>0 \cdot 3\right)$. The average proportional mortality of 24 and 48 initial recruits densities without predators were similar due to a special case at 24 initial recruit density $(0.46$ proportional mortality) that increased the average and standard deviation.
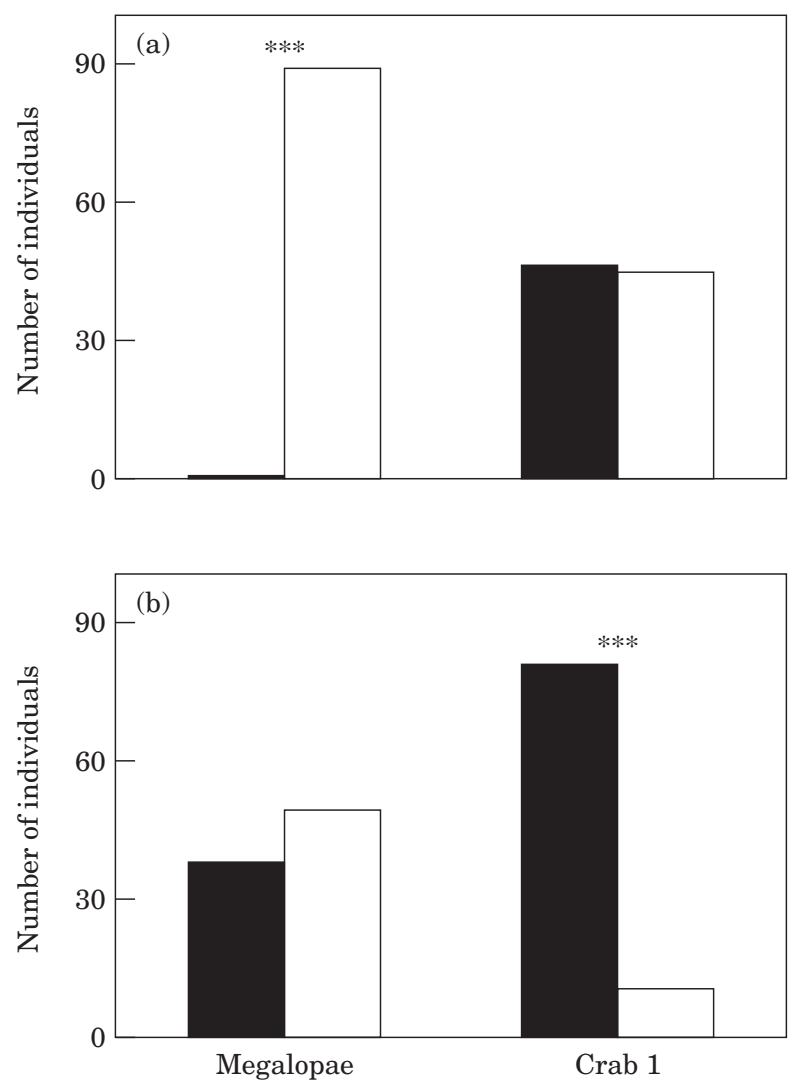

FiguRE 5. Substrate selection by megalopae and C1 of (a) Cyrtograpsus angulatus and (b) Chasmagnathus granulata. Bars represent the number of individuals found in reef of Ficopomatus enigmaticus or in mud (pooled data from 10 replicates with 10 individuals each). The total number is not 100 because some animals were swimming or resting in other parts of containers. ${ }^{* * *} P<0 \cdot 001, \chi^{2}$ test. Mud; $\square$ Reef.

Substrate selection. From 100 Cyrtograpsus angulatus megalopae released in the container, 89 were recovered in the reef, 1 in the mud and 10 were swimming or resting. This pattern was nonrandom $\left(\chi^{2}=86\right.$, and $P<0 \cdot 001)$. Conversely, C1 exhibited no significant differences in distribution between substrates (45 C1 in reef and 46 in mud) (Figure 5). The distribution of Chasmagnathus granulata megalopae did not differ significantly between substrates: 49 megalopae were recovered in the reef, 38 in the mud and 13 were swimming or resting. However, C1 showed significant differences in selection of substrate $\left(\chi^{2}=29 \cdot 3\right.$, $P<0.001): 11 \mathrm{C} 1$ were recovered in the reef and 81 in the mud (Figure 5).

Adult avoidance behaviour. Recruits were distributed evenly between the two sides of the control experiments (Figure 6). Recruits of Cyrtograpsus angulatus preferred the side not occupied by conspecific adults 


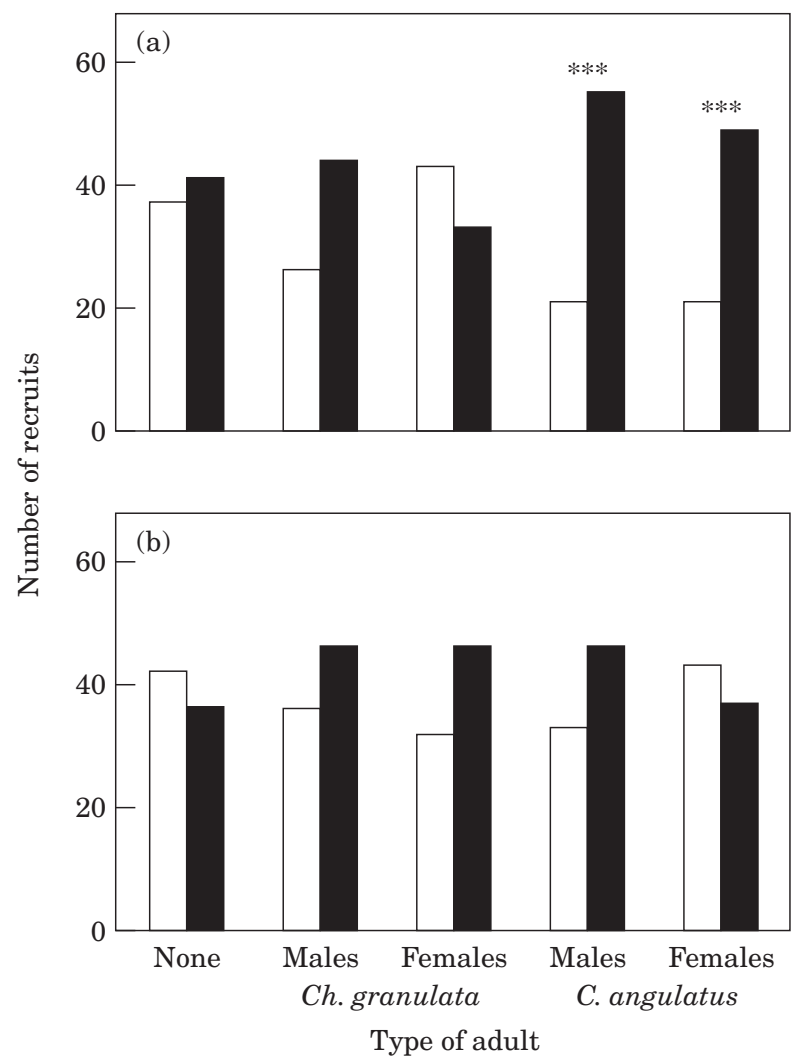

Figure 6. Adult avoidance behaviour by recruits of Cyrtograpsus angulatus and Chasmagnathus granulata. Bars represent the number of recruits (pooled data) in each side of the container after $15^{\prime}$ Eight replicates were used for each combination of recruits and adults of the two species, plus controls without adults. $* * * P<0 \cdot 01, \chi^{2}$ test. $\square$ With adults; without adults.

(males $\chi^{2}=7 \cdot 09$, females $\chi^{2}=5 \cdot 03 ; P<0.01$ ) and the presence of adult $C$. granulata males affected in a similar manner, but numbers appear lower and differences were not significant. The distribution of recruits of Chasmagnathus granulata was not significantly affected by the presence of adults of either species, but there was a trends toward avoidance of conspecifics (Figure 6). There was no effect of adult sex of the adults on recruit behaviour.

\section{Discussion}

Recruitment patterns of Cyrtograpsus angulatus and Chasmagnathus granulata in Mar Chiquita Coastal Lagoon were similar and consistent, and agree with the previous information available on distribution, growth and reproduction (Anger et al., 1994; Spivak et al., 1996, Bas unpublished data) and with the occurrence of intra- and inter-cohort cannibalism and predation (Luppi, 1999). Moreover, the fidelity of recruits and juveniles of each species to their specific habitat was maintained during the total sampling period.

After the lowest juvenile density registered at the end of spring, the arrival of first recruits causes a dramatic increase in the population number of both species. Recruits were then found during summer, autumn and winter but their numbers oscillated. Peaks of recruitment seemed to follow peaks of reproductive activity (Spivak et al., 1996). This pattern was more clear in Chasmagnathus granulata; recruitment of Cyrtograpsus angulatus is continuous but peaks of high density were always evident. Larvae produced by the last group of ovigerous females left the lagoon during fall. Colder temperatures would lengthen their larval development in the sea, possibly explaining the observed peaks of recruitment during early winter (e.g. megalopae of $C$. granulata were found in June 1994). Low temperatures may also stop growth of recruits and juveniles of both species (Luppi, 1999), causing the maintenance of high recruit and juvenile winter densities. On the other hand, ovigerous females of $C$. angulatus were found all year round in rocky shores $35 \mathrm{~km}$ south of Mar Chiquita, (Rognone, unpublished), allowing the occasional input of megalopae of this species, even in winter.

A model of the recruitment of Cyrtograpsus angulatus is shown in Figure 7. Megalopae, but not C1 crabs, actively selected reefs of Ficopomatus enigmaticus. Laboratory experiments showed that without refuge their mortality by cannibalism or predation was $100 \%$ (Luppi, 1999). Refuge availability was required for the survival of recruits of this species and the selection of a suitable settlement habitat was crucial for a successful recruitment. The avoidance of adult conspecifics by recruits of $C$. angulatus may be a mechanism of reinforcement of habitat selection by megalopae, as happened in Cancer magister (Fernandez et al., 1993b). Juveniles had similar densities in Ficopomatus enigmaticus reefs from summer to the end of the following spring, even after the input of new recruits during this period. This stability could be explained by juvenile growth and emigration (after reaching $7 \mathrm{~mm} \mathrm{CW}$, there is not enough space between the polychaete tubes) and a continuous replacement from new recruits. A recruit entering the reef leaves it after 30 to 45 days (Luppi, 1999). After leaving the reef, juveniles may be strongly preyed by conspecific adults (Gavio \& Iribarne, 1994).

However, the replacement of juveniles by growth of recruits did not explain the abrupt drop in recruit density, which may be caused by predation and cannibalism. Inside reefs, the only potential predators 


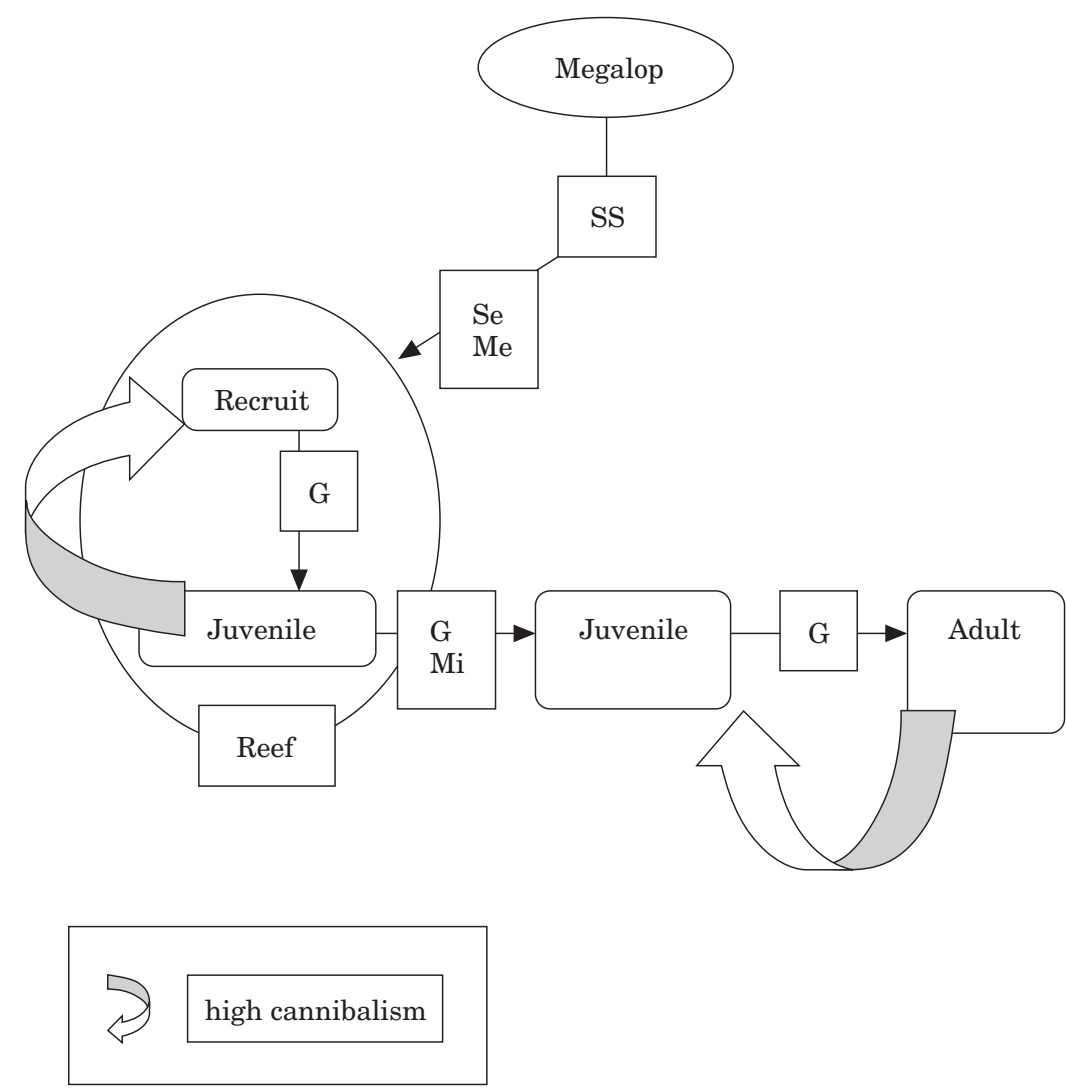

FIgURE 7. Model of recruitment of Cyrtograpsus angulatus in Mar Chiquita, including settlement and post-settlement processes: substrate selection (SS), settlement (Se), metamorphosis (Me), growth (G), and migration (Mi). Larvae develop in the sea; megalopae enter the lagoon few days before metamorphosis. Recruits were only found in Ficopomatus enigmaticus reefs; juveniles and adults in mud flats. The arrows indicate high cannibalism.

were juveniles of $C$. angulatus, adults of Cyrtograpsus altimanus and Gobiosoma parri (Gobidae), the latter two with low population numbers (Valero \& Luppi, unpublished data). Our experiments showed that, even in the presence of refuges, cannibalism and predation on recruits may be very intense in $C$. angulatus. A high proportional mortality due to intraand inter-cohort cannibalism may cause an underestimation of the number of recruitment peaks detected in the sampling programme: each of the two summer samplings were separated by $c a$. 10 days, a settlement event could have occurred and the subsequent increment in recruit density may have been obscured by cannibalism. On the other hand, our field experiments showed a strong density-dependent mortality of recruits due to intra- and inter-cohort cannibalism. Where density-independent mortality occurs, the proportional mortality is constant; when mortality is density-dependent, the proportional mortality increase with prey densities (Caley et al., 1996). In our case, the proportional mortality due to intra- and inter-cohort cannibalism increased significantly (three times) with the prey densities. This implies that, independent of recruitment intensity, the peaks of high recruitment were not transmitted to larger size classes as shown by Luppi (1999).

A model of the recruitment of Chasmagnathus granulata is shown in Figure 8. Megalopae of Chasmagnathus granulata did not prefer a settlement substrata. Field observations are consistent with these results. Megalopae and recruits have been observed in stones and shells, on reefs, and in conspecific burrows but they disappeared from the reefs two days after settlement (Luppi, unpublished data). In reefs, they are likely to be predated by C. angulatus (Luppi, 1999) or they migrate to muddy habitat (C1 selected mud in our experiments). In the adult habitat, megalopae were found exclusively in the interior of the burrows. The selection of this microhabitat for settlement may have a number of benefits: (1) settlement in a suitable habitat for the burrowing activity soon after metamorphosis; (2) passive protection by adults, which repel potential predators such as other crabs, juvenile conspecifics and birds; and (3) adult induction of 


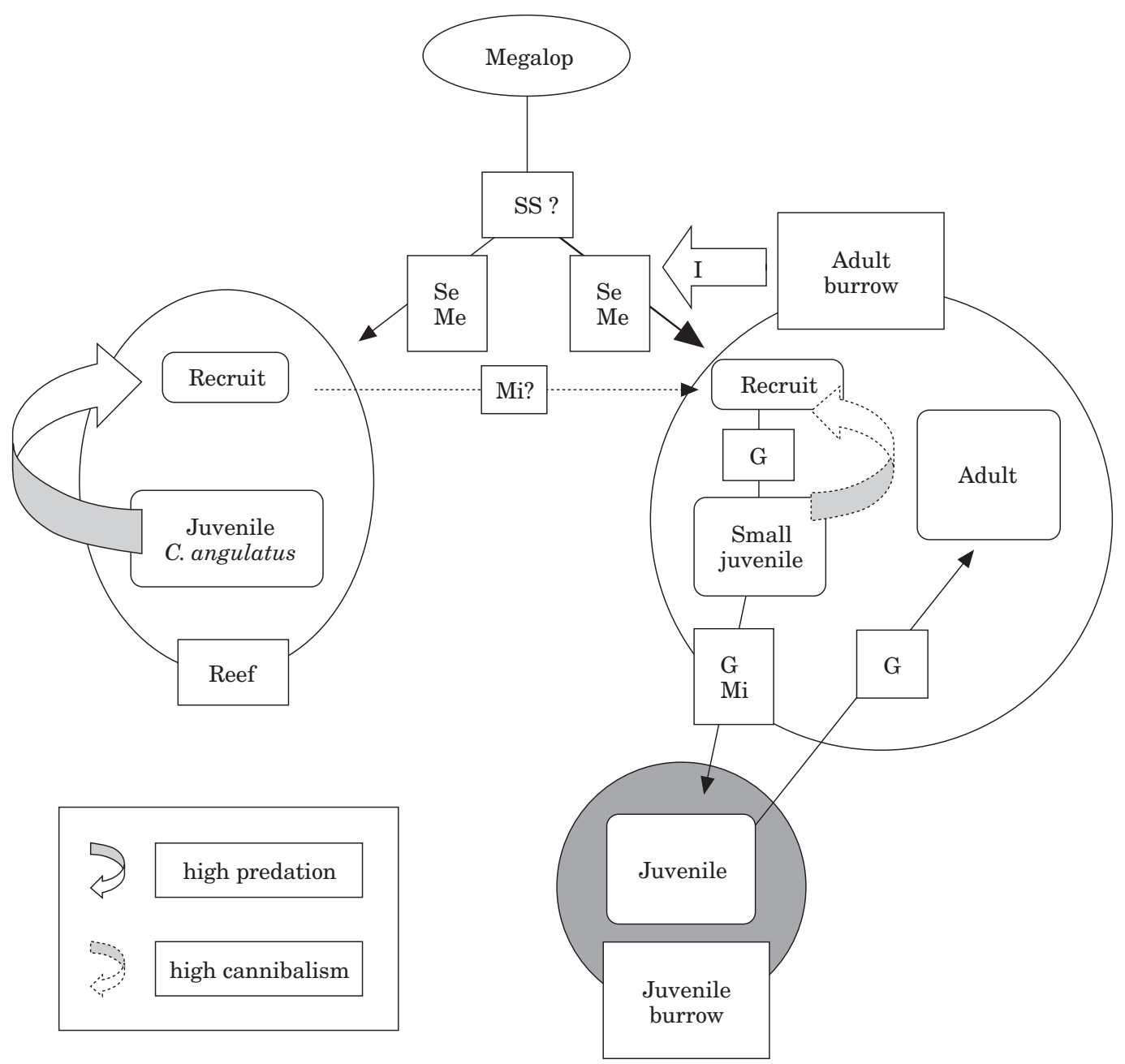

FiguRE 8. Model of recruitment of Chasmagnathus granulata in Mar Chiquita, including settlement and post-settlement processes: substrate selection, settlement, metamorphosis, growth, migration and adult induction of megalopal metamorphosis (I, the other references as in Figure 7). Larvae develop in the sea; megalopae enter the lagoon few days before metamorphosis. Recruits were mainly found in adult burrows, juveniles gradually leave these burrows; some recruits (only first crabs) were found in Ficopomatus enigmaticus reefs. The arrows indicated high predation and low cannibalism (dotted line).

metamorphic moult (Gebauer et al., 1997), increasing the probability of permanence in the burrow as first instar. One could expect recruits to be attracted towards adult conspecifics, but this was not found in our experiments. Adult females preyed on recruits, although less than juveniles (Luppi, 1999) but the recruit-adult interaction seems to be complex, since sometimes recruits were observed on adult carapace and legs (Luppi, unpublished data). Juveniles larger than $4 \mathrm{~mm} \mathrm{CW}$ began to built their burrows without communication with adult ones. Juvenile density fluctuated more, and recruit density less, than Cyrtograpsus angulatus.

Recruitment peaks were followed by peaks of juveniles, that in 1993 and 1995 (but not in 1994) were smaller (Figure 2). Larval production is more synchronized in C. granulata (Spivak et al., 1996) and settlement and recruitment could be more episodic events, though not necessarily more regular. Cannibalism of juveniles over recruits also occurs in C. granulata but was less intense than in C. angulatus (Luppi et al., 2001): recruits mainly inhabit adult burrows far from most juveniles, which had their own burrows. Reefs protect $C$. angulatus recruits against predators; conversely $C$. granulata recruits are exposed to a much wider array of predators including birds, crabs, and fish that may explain the declines in their densities.

Recruitment depends on three factors: (1) the amount of megalopae in the water column; (2) active 
selection of settlement habitats by megalopae; and (3) survival of recruits and first juvenile stages. Preliminary samples of $C$. angulatus megalopae in the water column showed a positive relationship with the amount of recruits; the pattern in C. granulata was not so clear (Luppi, unpublished data).

Megalopae of both species were able to swim and manoeuvre in running water conditions similar to the ones found at field sites (Valero et al., 1999). They had the time to find and select specific settlement habitats, since most entered the lagoon in intermoult and had several days to metamorphose to first crab (Luppi \& Spivak, 1999). However, only C. angulatus megalopae showed clear settlement habitat selection in the field. Conversely, it is difficult to explain the high proportion of $C$. granulata megalopae found in reefs, having in mind the null recruitment success of this species in this habitat.

The abrupt density drops after high recruitment peaks may be explained by intra- and inter-specific predation or migration. Laboratory and field experiments (Luppi, 1999, this work) showed that mortality due to juvenile predation and cannibalism were important factors to explain the significant postsettlement mortality, even in the presence of alternative preys. Moreover, inter-cohort cannibalism had an important density-dependent component at least in Cyrtograpsus angulatus, and even intra-cohort cannibalism played an important role at high recruit density. On the other hand, recruits that emigrate from the settlement habitat would be strongly exposed to other predators since other refuges were not available: no recruits survived without refuges in laboratory experiments (Luppi, 1999).

Summarizing, we showed that post-settlement processes strongly affect the recruitment pattern of both species; consequently, they have a regulated recruitment. However, the degree of such regulation is different. Cyrtograpsus angulatus recruits disappeared after a peak of high recruitment, and peaks did not transferred to juveniles populations, while the strong recruitment events of Chasmagnathus granulata are followed shortly by similar increases of juveniles. Moreover, the mortality due to cannibalism is greater in $C$. angulatus. In the last species, the regulation of recruitment seems to be more intense than in C. granulata.

\section{Acknowledgements}

We thank C. Bas and R. Zenuto for their field and laboratory assistance. This research was part of a bilateral cooperation programme (MAR-8) between the Universidad Nacional de Mar del Plata
(UNMDP), Argentina, and the Biologische Anstalt Helgoland, Germany. It was funded by Consejo Nacional de Investigaciones Científicas y Técnicas de la República Argentina (CONICET) and UNMdP grants to E.S. (PIP 838/98 and 15/E149) and fellowships to T.L., the Secretaría de Ciencia y Tecnología (Buenos Aires) and, on behalf of the German Federal Ministry of Education, Science and Technology (Bonn), by the International Bureau of the Alfred Wegner Institut fur Polar- und Meersforschung (Bremerhaven, Germany) and the Forshungszentrum Julich GmbH (Julich, Germany). J.V. was supported by Fundacion Antorchas, UNMdP and the Fulbright programme. This study represent a portion of T.L. Ph.D. dissertation.

\section{References}

Anger, K., Bas, C., Spivak, E., Ismael, D. \& Luppi, T. 1994 Hatching rhythms and dispersion of decapod crustacean larvae in a brackish coastal lagoon in Argentina. Helgolander Meeresuntersuchungen 48, 445-466.

Bell, J. D. \& Westoby, M. 1986 Abundance of macrofauna in dense seagrass is due to habitat preference, not predation. Oecologia 68, 205-209.

Bertness, M. D., Gaines, S. D., Stephens, E. G. \& Yund, O. Y. 1992 Components of recruitment in populations of the acorn barnacle, Semibalanus balanoides (Linnaeus). Fournal of Experimental Marine Biology and Ecology 156, 199-215.

Botero, L. \& Atema, J. 1982 Behavior and substrate selection during larval settling in the lobster Homarus americanus. Fournal of Crustacean Biology 2, 59-69.

Butler, M. J., Herrnkind, W. F. \& Hunt, J. H. 1997 Factors affecting the recruitment of juvenile caribbean spiny lobsters dwelling in macroalgae. Bulletin of Marine Science 61, 3-19.

Caley, M. J., Carr, M. H., Hixon, M. A., Hughes, T. P., Jones, G. P. \& Menge, B. A. 1996 Recruitment and the local dynamics of open marine populations. Annual Review of Ecology and Systematics 27, 477-500.

Caputi, N., Chubb, C. F. \& Brown, R. S. 1995 Relationship between spawning stock, environment, recruitment, and fishing effort for the western rock lobster, Panulirus cygnus, fishery in Western Australia. Crustaceana 68, 213-226.

Connell, J. H. 1985 The consequences of variation in initial settlement vs. post-settlement mortality in rocky intertidal communities. Fournal of Experimental Marine Biology and Ecology 93, 11-45.

D’Incao, F., Da Silva, K. G., Ruffino, M. L. \& Da Costa Braga, A. 1990 Habito alimentar do caranguejo Chasmagnathus granulata Dana, 1851 na barra do Rio Grande, RS (Decapoda, Grapsidae). Atlantica, Rio Grande, Brasil 12, 85-93.

Doherty, P. J. \& Williams, D. M. 1988 The replentishment of coral reef fish populations. Oceanography and Marine Biology Annual Review 26, 487-551.

Eggleston, D. B. \& Lipcius, R. N. 1992 Shelter selection by spiny lobster under variable predation risk, social conditions, and shelter size. Ecology 73, 992-1011.

Eggleston, D. B. \& Armstrong, D. A. 1995 Pre- and post-settlement determinants of estuarine dungeness crab recruitment. Ecological Monographs 65, 193-216.

Fasano, J. L., Hernández, M. A., Isla, F. I. \& Schnack, E. J. 1982 Aspectos evolutivos y ambientales de la laguna Mar Chiquita (Provincia de Buenos Aires, Argentina). Oceanologica Acta 5, 285-292. 
Fernández, M., Armstrong, D. \& Iribarne, O. 1993a First cohort of young-of-the-year Dungeness crab, Cancer magister, reduces abundances of subsequent cohorts in intertidal shell habitat. Canadian Fournal of Fisheries and Aquatic Sciences 50, 2100-2105.

Fernández, M., Iribarne, O. \& Armstrong, D. 1993b Habitat selection by young-of-the-year Dungeness crab Cancer magister and predation risk in intertidal habitats. Marine Ecology Progress Series 92, 171-177.

Fernández, M., Iribarne, O. \& Armstrong, D. 1994 Swimming behavior of Dungeness crab, Cancer magister Dana megalopae in still and moving water. Estuaries 17, 282-286.

Gaines, S. D. \& Roughgarden, J. 1985 Larval settlement rate, a leading determinant of structure in an ecological community of the marine intertidal zone. Proceedings of the National Academy of Sciences, USA 82, 3701-3711.

Gavio, A. \& Iribarne, O. 1994 Distribucisó espacial, selección de hábitat y tasa de mortalidad de Cyrtograpsus angulatus en la albúfera Mar Chiquita: la importancia del canibalismo. II Taller sobre cangrejos y cangrejales. Mar del Plata.

Gebauer, P., Walter, I. \& Anger, K. 1998 Effect of substratum and conspecific adults on the metamorphosis of Chasmagnathus granulata (Dana) (Decapoda, Grapsidae) megalopae. Fournal of Experimental Marine Biology and Ecology 223, 185-198.

Gutierrez, J. L. \& Iribarne, O. 1999 Role of Holocene beds of the stout razor clam Tagelus plebeius in structuring present benthic communities. Marine Ecology Progress Series 185, 213-228.

Heck, K. L. \& Orth, R. J. 1980 Seagrass habitats, the role of habitat complexity, competition and predation in structuring associated fish and motile macroinvertebrate assemlages. In In Estuarine Perspectives (Kennedy, V. S., ed.). Academic Press, New York, pp. 449-464.

Hedvall, O., Moksnes, P. \& Phil, L. 1998 Active habitat selection by megalopae and juvenile shore crabs Carcinus maenas, a laboratory study in a annular flume. Hydrobiologia 375/376, 89-100.

Herrnkind, W. F. \& Butler, M. J. 1986 Factors regulating postlarval settlement and juvenile mecrohabitat use by spiny lobster Panulirus argus. Marine Ecology Progress Series 34, 23-30.

Hughes, T. P. 1990 Recruitment limitation, mortality, and population regulation in open system, a case study. Ecology 71, 12-20.

Incze, L. S. \& Wahle, R. A. 1991 Recruitment from pelagic to early benthic phase in lobsters Homarus americanus. Marine Ecology Progress Series 79, 77-87.

Iribarne, O., Bortolus, A. \& Botto, F. 1997 Between-habitat differences in burrow characteristics and trophic modes in the southwestern Atlantic burrowing crab Chasmagnathus granulata. Marine Ecology Progress Series 155, 137-145.

Luckenbach, M. W. \& Orth, R. J. 1992 Swimming velocities and behavior of blue crab (Callinectes sapidus Rathbun) megalopae in still and flowing water. Estuaries 15, 186-192.

Luppi, T., Spivak, E. \& Anger, K. 1994 La coexistencia de dos especies de cangrejo en el ecosistema del cangrejal: estudio comparativo del asentamiento y el reclutamiento. Abstract. II Taller sobre Cangrejos y Cangrejales, Mar del Plata, Argentina.

Luppi, T. A. 1999 La coexistencia de dos especies de cangrejo en el ecosistema del cangrejal, estudio comparativo del asentamiento y el reclutamiento (The coexistence of two crab species in the ' cangrejal' ecosystem, comparative study of settlement and recruitment). Doctoral Thesis. Universidad Nacional de Mar de Plata, Argentina, $101 \mathrm{pp}$.

Luppi, T. \& Spivak, E. 1999 Coloración, estadio de muda, reservas energéticas y tiempo hasta la metamorfosis en megalopas de Chasmagnathus granulata y Cyrtograpsus angulatus en la laguna Mar Chiquita. Abstract. IV Taller sobre Cangrejos y Cangrejales. Buenos Aires, Argentina.
Luppi, T., Spivak, E. \& Anger, K. 2001 Experimental studies of predation and cannibalism in recruits of Chasmagnathus grannulata and Cyrtograpsus angulatus (Brachyura: Grapsidae). Fournal of Experimental Marine Biology and Ecology 265, 29-48.

Mapstone, B. D. \& Fowler, A. J. 1988 Recruitment and the structure of assemblage of fish on coral reefs. Trends in Ecology and Evolution 3, 72-77.

Moksnes, P., Lipcius, R., Pihl, L. \& van Montfrans, J. 1997 Cannibal-prey dynamics in young juveniles and postlarvae of the blue crab. Fournal of Experimental Marine Biology and Ecology 215, 157-187.

Moksnes, P. O. 1999 Recruitment regulation in shore crab. Doctoral Thesis. Göteburg University, Sweden.

Olivier, S., Escofet, A., Penchaszadeh, P. \& Orensanz, J. $1972 a$ Estudios ecológicos de la región estuarial de Mar Chiquita (Bs. As., Argentina). I. Las comunidades bentónicas. Anales de la Sociedad Científica Argentina 193, 237-262.

Olivier, S., Escofet, A., Penchaszadeh, P. \& Orensanz, J. $1972 b$ Estudios ecológicos de la región estuarial de Mar Chiquita (Bs. As., Argentina). II. Relaciones tróficas interespecíficas. Anales de la Sociedad Científica Argentina 194, 89-104.

Olmi, E. J., van Montfrans, J., Lipcius, R. N., Orth, R. J. \& Sadler, P. W. 1990 Variation in planktonic availability and settlement of blue crab megalopae in the York River, Virginia. Bulletin of Marine Science 46, 230-243.

Palma, A. T., Wahle, R. A. \& Steneck, R. S. 1998 different early postsettlement strategies between American lobsters Homarus americanus and rock crabs Cancer irroratus in the Gulf of Maine. Marine Ecology Progress Series 162, 215-225.

Palmer, M. A., Allan, J. D. \& Butman, C. A. 1996 Dispersal as a regional process affecting the local dynamics of marine and stream invertebrates. Trends in Ecology and Evolution 11, 322-326.

Pearse, A. F. \& Phillips, B. F. 1988 ENSO events, the Leeuwin Current, and larval recruitment of the western rock lobster. ICES fournal of Marine Science 45, 13-21.

Reta, R., Martos, P., Piccolo, M. C., Perillo, G. M. \& Ferrante, A. 1997 Cracterísticas de la marea en la laguna costera Mar Chiquita, Argentina. Abstract. VII Congresso Latinoamericano sobre Ciencias do Mar, Santos, Brasil, pp. 330-332.

Schwindt, E. \& Iribarne, O. 2000 Settlement sites, survival and effects on benthos of an introduced reef-building polychaete in a SW Atlantic coastal lagoon. Bulletin of Marine Science 67, 73-82.

Spivak, E. D., Anger, K., Bas, C., Luppi, T. \& Ismael, D. 1996 Size structure, sex ratio, and breeding season in two intertidal grapsid crab species from Mar Chiquita lagoon, Argentina. Nerítica, Pontal do Sul, Parana, Brasil 10, 7-26.

Spivak, E. D., Anger, K., Luppi, T. A., Bas, C. \& Ismael, D. 1994 Distribution and habitat preferences of two grapsid crab species in Mar Chiquita lagoon (Province of Buenos Aires, Argentina). Helgolander Meeresuntersuchungen 48, 59-78.

Steger, R. 1987 Effects of refuges and recruitment on gonodactylid stomatopods, a guild of mobile prey. Ecology 68, 1520-1533.

Stoner, A. W. 1980 Perception and choice of substratum by epifaunal amphipods associated with seagrasses. Marine Ecology Progress Series 3, 105-111.

Valero, J., Luppi, T. A. \& Iribarne, O. 1999 Size as indicator of swimming speed of crab megalopae. Fournal of Shellfish Research 18, 663-666.

Wahle, R. \& Steneck, R. S. 1991 Recruitment habitats and nursery grounds of the American lobster Homarus americanus, a demographic bottleneck? Marine Ecology Progress Series 69, 231-243. 